\title{
The effects of nettle (Urtica dioica), spiny sowthistle (Sonchus asper) and dandelion (Taraxacum officinale) on the fish quality during storage period
}

\author{
Isırgan (Urtica dioica), eşek gevreği (Sonchus asper) ve karahindiba \\ (Taraxacum officinale)'nın depolama süresince balık kalitesi üzerine etkileri
}

\author{
${ }^{1}$ Ege University, Faculty of Fisheries, 35100, Bornova - Izmir, Turkey (iD https://orcid.org/0000-0002-7105-2276 \\ ${ }^{2}$ Ege University, Faculty of Fisheries, 35100, Bornova - Izmir, Turkey (iD https://orcid.org/0000-0003-3203-5497 \\ ${ }^{3}$ Ege University, Faculty of Fisheries, 35100, Bornova - Izmir, Turkey (iD https://orcid.org/0000-0002-7061-8960 \\ ${ }^{4}$ Ege University, Faculty of Fisheries, 35100, Bornova - Izmir, Turkey (iD https://orcid.org/0000-0002-1745-1751 \\ ${ }^{5}$ Ege University, Faculty of Fisheries, 35100, Bornova - Izmir, Turkey iD https://orcid.org/0000-0002-1650-142X \\ *Corresponding author:omer.alper.erdem@ege.edu.tr
}

Can Altınelataman ${ }^{1} \bullet$ E. Burcu Şen Yılmaz ${ }^{2} \bullet$ Şebnem Tolasa Yılmaz ${ }^{3} \bullet$ Ömer Alper Erdem ${ }^{4 *} \bullet$ Ufuk Çelik $^{5}$

Received date: 11.07.2018 Accepted date: 10.09 .2018

\author{
How to cite this paper: \\ Altınelataman, C., Yılmaz Şen, E.B., Yılmaz, Ş.T., Erdem, Ö.A. \& Çelik, U. (2018). The effects of nettle (Urtica dioica), spiny \\ sowthistle (Sonchus asper) and dandelion (Taraxacum officinale) on the fish quality during storage period. Ege Journal of \\ Fisheries and Aquatic Sciences, 35(4), 423-431. DOI:10.12714/egejfas.2018.35.4.08
}

\begin{abstract}
The objective of this research was to examine the abilities to retard oxidation and microbial growth of three green-leaf plants on aquacultured seabass (Dicentrarchus labrax) fillets during refrigerated storage $\left(+4{ }^{\circ} \mathrm{C} \pm 2\right)$. For this purpose, dandelion (Taraxacum officinale), nettle (Urticia dioica) and spiny sowthistle (Sonchus asper) herbs commonly consumed as food in Aegean region were used. The protection capacities of the water extract and vapor distillates of the plants were investigated. After the fishes obtained from an aquaculture farm in Çeşme, were brought to the laboratory and filleted. The extracts and distillates of the plants were obtained using conventional cooking dosing and then fillets were applied at $10^{\circ} \mathrm{C}$ difference between them to increase the diffusion effect. Chemical, microbial and sensorial analyses were done until the fillets spoiled. Results showed that, TBARS values of all samples were under the recommended limits at the end of the storage period. Unlike the TBARS values, all samples were exceeded the recommended TVB-N limits except dandelion distillate samples at the end of the storage period. When all results are examined, the most important finding is that microbial growth was retarded in the samples treated with extracts.

It is concluded that extract and vapour distillates of nettle, dandelion and spiny sowthistle herbs could be used as a preservative to protect the quality and prolong the shelf-life of seafood.
\end{abstract}

Keywords: Seabass, quality changes, preservation, antioxidant, herbal additives

Öz: Bu çalışmanın amacı üç yeşil yapraklı bitkinin, buzdolabı şartlarında $\left(+4{ }^{\circ} \mathrm{C} \pm 2\right)$ depolanan levrek (Dicentrarchus labrax) filetolarındaki oksidasyonu, mikrobiyal gelişimi önleyebilirliklerini ölçmektir. Bu amaçla Ege Bölgesi'nde gıda olarak bolca tüketilen karahindiba (Taraxacum officinale), ısırgan (Urticia dioica) ve eşek gevreği (Sonchus asper) kullanılmıştır. Bitkilerin su fazı ekstrat ve su buharı distilatlarının toplamının koruma kapasiteleri araştııımışıı. Çeşme'de bulunan bir su ürünleri tesisinden elde edilen balıklar laboratuara getirilip fileto edildikten sonra, bitkilerin ekstrakt ve distilatları geleneksel pişirme dozajı kullanılarak elde edilmiş, daha sonra difüzyon etkisinin yüksek olması amacıyla aralarında $10^{\circ} \mathrm{C}$ fark olacak şekilde filetolara uygulanmıştır. $4^{\circ} \mathrm{C}$ 'de depolanan filetolar bozulana kadar kimyasal kalite parametreleri, mikrobiyolojik ve duyusal analizler tespit edilmiştir. Sonuçlar, tüm numunelerin TBA değerlerinin depolama süresinin sonunda önerilen sınırların altında olduğunu göstermiștir. TBA değerlerinin aksine, karahindiba distile numuneleri dışında tüm örnekler depolama periyodunun sonunda önerilen sınırları aşmışlardır. Tüm sonuçlar incelendiğinde en önemli bulgu, ekstrakte edilmiş örneklerin mikrobiyolojik gelişimi geciktirme kabiliyeti göstermesidir.

Isırgan, karahindiba ve eşek gevreği gibi bazı bitkilerin, kaliteyi korumak ve raf ömrünü uzatmak için deniz ürünlerinin işlenmesinde koruyucu olarak kullanılabileceği sonucuna varılmıştır.

Anahtar kelimeler: Levrek , kalite değişimi, koruma, antioksidan, bitkisel katkılar 


\section{INTRODUCTION}

Herbs have been used for a great variety of objectives. They have been found to be natural antioxidants' important sources. Some of them have been used for hundreds of years, and their clinical and pharmacological effects have been widely investigated from various standpoints. Some clinical effects of herbs closely regard with their antioxidant activities. The researches on the extending shelf-life of the food by use of natural antioxidants gained increasing interest.

It has been demonstrated that the quality loss of food can be prevented by using antioxidants due to their preventive or delaying their oxidative deterioration during processing and storage. Wild fruits, plants and vegetables have allured much attention as sources of natural antioxidants. Many of the wild fruits, plants and vegetables have antioxidants such as polyphenols (catechins, flavonoids, tannins) and vitamins ( $\beta$-carotene, vitamins $C$ and $E$ ) (Alpınar et al., 2009). While some synthetic antioxidant compounds such as butylated hydroxytoluene $(\mathrm{BHT})$ and butylated hydroxyanisole (BHA) are commonly used in processed foods, it has been reported that these chemical compounds may have side effects. Only few researches available about antioxidant effects of dandelion on fish (Tan et al., 2018). On the other hand, several researchers were focused on antimicrobial and antioxidant effects of mentioned herbs on food products (Aksu and Kaya, 2004; Biel et al., 2017; El-Alim et al., 1999; Frankel et al., 1996; Gülçin et al., 2004; Ivanov, 2014; Karabacak and Bozkurt, 2008; Mavi et al., 2004; Oz, 2014; Ozyurt et al., 2007; Shah et al., 2014). Biel et al., (2017) have studied on the chemical composition and antioxidant properties of common dandelion leaves contrasted with sea buckthorn and indicated that the leaves of dandelion and sea buckthorn may be used as good source of biologically active substances in the human diet.

Most articles on nettle are related to medical studies and they demonstrated positive medical effects of nettle (Alirezalu, Hesari, Eskandari, Valizadeh, \& Sirousazar, 2017; Avcl, Kupeli, Eryavuz, Yesilada, \& Kucukkurt, 2006; Bnouham et al., 2003; Randall, Meethan, Randall, \& Dobbs, 1999; Testai et al., 2002; Toldy et al., 2005; Yener, Celik, Ilhan, \& Bal, 2009). Özen and Korkmaz (2003) have reported that the activities of cytochrome b5 (cyt b5), NADH-cytochrome b5 reductase (cyt b5 R), glutathione S-transferase (GST), DT-diaphorase (DTD), glutathione peroxidase (GPx), glutathione reductase (GR), superoxide dismutase (SOD) and catalase (CAT) showed an important rise in the liver at 50 and $100 \mathrm{mg} / \mathrm{kg}$ body dose levels of Urtica dioica extract. Haghju et al., (2016) have performed investigation to identify and contrast antimicrobial, physical and mechanical properties of chitosan-based films, involving free or nanoencapsulated nettle (Urtica dioica L.) extract. Researchers reported that the probable antimicrobial activity of the films comprising NEloaded nanoliposomes against Staphylococcus aureus was diminished in proportion to free NE-incorporated films, which could be based on the inhibition effect of the encapsulation that hinders the release of NE from the matrix.

Choi et al., (2010) notified that dandelion has beneficial effect in prohibiting hypercholesterolemic atherosclerosis and decreasing risk factors for coronary artery disease. Ovadje et al., (2011) have reported that dandelion root aqueous extract induces apoptosis in human leukemia cell lines. Dandelion water extract can improve the lipid metabolism and is useful in prohibiting diabetic complications from lipid peroxidation and free radicals in diabetic rats (Cho et al., 2002). Hu and Kitts (2005), have reported that the dandelion flower extract marked antioxidant activity in both chemical and biological models and the efficacy of it in inhibiting both reactive nitric oxide and oxygen species were bound to its phenolic content. Khan (2017) evaluated the antidiabetic activity of a Sonchus asper methanol extract (SAME) in rats and concluded that the important antidiabetic potential of the SAME in ameliorating the diabetic conditions in diabetic rats might be due to the existence of the bioactive components in the extract. Khan et al., (2012) have suggested that Sonchus asper composed of active components; displaying preservative effects against the toxic effects of carbon tetrachloride $\left(\mathrm{CCl}_{4}\right)$ in lung of rat.

In this study, it is aimed to investigate the effect of three green-leaf plant, (nettle, spiny sowthistle and dandelion) extracts on the quality changes of seabass (Dicentrarchus labrax) fillets during refrigerated storage $\left(4 \pm 2^{\circ} \mathrm{C}\right)$.

\section{MATERIAL AND METHODS \\ Preparation and treatment of samples}

Herbs were purchased as fresh from local bazaar in Izmir and transferred to the laboratory. Seabass (Dicentrarchus labrax) were taken from an aquaculture farm in Çesme and transferred in iced box to the laboratory within 2 hours. All samples were headed, gutted and filleted in the laboratory.

All herbs washed with tap water and allowed to drain for $30 \mathrm{~min}$. Each plant was distilled by using herb:water mixture $(2: 5, \mathrm{w}: \mathrm{v})$ (400 gr plant $+1000 \mathrm{ml}$ water). Distillates and extracts were obtained with traditional cooking dosage, applied separately to fillets with $10^{\circ} \mathrm{C}$ temperature difference for increased diffusion efficiency $(1 / 1,100 \mathrm{ml}+100 \mathrm{~g}$ fillet, $30 \mathrm{~min}$.). Two fillets were inserted in a styrofoam tray and packaged by over-wrapping with polyvinylidene film. The packaged fillets were stored at $4^{\circ} \mathrm{C}$. Samples were analysed on 0 , 
$2,5,7,9$ and 12 days of the storage period.

\section{Analysis}

\section{Total volatile bases nitrogen (TVB-N) analysis}

TVB-N analysis was done according to the method proposed by the Codex Alimentarius Committee in 1968 as modified by Malle and Poumeyrol (1989).

\section{Thiobarbituric acid (TBA) analysis}

Thiobarbituric acid (TBA) was determined according to Tarladgis et al. (1960).

\section{Microbiological analysis}

Total aerobic mesophilic bacteria counts (TAMBC) were determined by Rohde, 2007 and psycrotrophic bacteria counts (PBC) were determined by Ariyapitipun et al. (1999).

\section{Sensorial analysis}

Closed system-vapour cooking apparatus was used to prepare samples for sensory test. Sensorial analysis were performed to the method from Carbonell et al. (2002).

\section{Statistical analysis}

Statistical analysis was carried out using SPSS (SPSS, 1999, Version 16.0. Chicago, IL, USA) followed by Duncan's multiple range test. The test was used to compare the differences among means. The results are presented as means $\pm S D$ with the significance level set at $p<0.05$ under varying storage periods.

\section{RESULTS AND DISCUSSION}

\section{Changes in chemical quality parameters}

One of the most commonly used methods for monitoring lipid oxidation in meat products is the 2-thiobarbituric acid (TBA) test. The steam distillation method of Tarladgis et al., (1960) in which a portion of the distillate is directly reacted with an acidic TBA reagent is frequently used to follow lipid oxidation. The TBA analysis results of the seabass are given in Table 1.

Table 1. TBA results of the samples (mg malonaldehyde $/ \mathrm{kg}$ )

\begin{tabular}{lcccccc}
\hline \multirow{2}{*}{ Samples } & $\mathbf{5}$ & $\mathbf{2}$ & $\mathbf{5}$ & $\mathbf{7 .}$ & $\mathbf{9 .}$ & $\mathbf{1 2}$ \\
\hline $\mathbf{C}$ & $0.14 \pm 0.02^{\mathrm{a} 2}$ & $0.12 \pm 0.01^{\mathrm{bd} 2}$ & $0.23 \pm 0.00^{\mathrm{b} 1}$ & $0.24 \pm 0.00^{\mathrm{b} 1}$ & $0.24 \pm 0.00^{\mathrm{e} 1}$ & $0.23 \pm 0.00^{\mathrm{e} 1}$ \\
$\mathbf{N D}$ & $0.13 \pm 0.01^{\mathrm{a} 6}$ & $0.21 \pm 0.01^{\mathrm{a} 4}$ & $0.24 \pm 0.01^{\mathrm{b} 3}$ & $0.17 \pm 0.01^{\mathrm{e} 5}$ & $0.43 \pm 0.00^{\mathrm{a} 2}$ & $0.47 \pm 0.01^{\mathrm{b} 1}$ \\
$\mathbf{N E}$ & $0.12 \pm 0.00^{\mathrm{a} 6}$ & $0.15 \pm 0.01^{\mathrm{b} 5}$ & $0.27 \pm 0.00^{\mathrm{a} 4}$ & $0.31 \pm 0.01^{\mathrm{a} 3}$ & $0.35 \pm 0.01^{\mathrm{b} 2}$ & $0.48 \pm 0.02^{\mathrm{b} 1}$ \\
SD & $0.18 \pm 0.05^{\mathrm{a} 2}$ & $0.14 \pm 0.02^{\mathrm{bc} 2}$ & $0.20 \pm 0.02^{\mathrm{c} 2}$ & $0.19 \pm 0.00^{\mathrm{d} 2}$ & $0.28 \pm 0.00^{\mathrm{cd} 1}$ & $0.34 \pm 0.00^{\mathrm{c} 1}$ \\
SE & $0.13 \pm 0.00^{\mathrm{a} 4}$ & $0.09 \pm 0.00^{\mathrm{d} 5}$ & $0.22 \pm 0.01^{\mathrm{bc} 3}$ & $0.23 \pm 0.00^{\mathrm{bc} 3}$ & $0.27 \pm 0.01^{\mathrm{d} 2}$ & $0.51 \pm 0.00^{\mathrm{a} 1}$ \\
DD & $0.14 \pm 0.00^{\mathrm{a} 34}$ & $0.10 \pm 0.03^{\mathrm{cd} 4}$ & $0.15 \pm 0.00^{\mathrm{d} 3}$ & $0.22 \pm 0.00^{\mathrm{c} 2}$ & $0.25 \pm 0.02^{\mathrm{de} 2}$ & $0.32 \pm 0.00^{\mathrm{cd} 1}$ \\
DE & $0.15 \pm 0.00^{\mathrm{a} 4}$ & $0.08 \pm 0.00^{\mathrm{d} 5}$ & $0.20 \pm 0.01^{\mathrm{c} 3}$ & $0.19 \pm 0.01^{\mathrm{d} 3}$ & $0.28 \pm 0.01^{\mathrm{c} 2}$ & $0.31 \pm 0.00^{\mathrm{d} 1}$ \\
\hline
\end{tabular}

C: Control; ND: Nettle Distillate; NE: Nettle Extract; SD: Sowthistle Distillate; SE: Sowthistle Extract; DD: Dandelion Distillate; DE: Dandelion Extract

* Means in the same column with the same latter and means in the same line with the same number do not differ significantly at the level of

$\mathrm{P}<0.05$ significance.

The initial TBA values of all samples were all low, ranging from 0.12 to 0.18 . At the end of the $12^{\text {th }}$ day of storage at refrigerator, the lowest TBA value was found in the control group (0.23) and the highest was found in the sowthistle extract treated samples (0.51) which means none of the samples reached the admissible limit of $1 \mathrm{mg}$ malonaldehyde/ $\mathrm{kg}$. The sample groups of ND, NE and SE contained higher TBA values than others with significant differences at day 12 . On the other hand, TBA values at the end of storage trial were found to be recommended limit. Since TBA values of control group was also determined in very low levels, indication of oxidation is not problem for this species for the experimented storage period due to its low fat value.

Packaging methods and addition of antioxidants affect TBA values. Gülçin et al., (2004), have studied the antioxidant and antimicrobial effects of WEN (Water Extract of Nettle), and reported that on the basis of the outcomes of their work, it is unambiguously referred that WEN has a strong antioxidant activity against various oxidative systems in vitro; additionally, WEN can be used as gainable source of natural antioxidants and as a potential food supplement or in pharmaceutical industry. Karabacak and Bozkurt (2008) have studied the effects of Urtica dioica and Hibiscus sabdariffa on 
the quality and safety of sucuk (Turkish dry-fermented sausage) and reported that Urtica dioica was more effecient on reducing histamine formation than the nitrite/nitrate and BHT. Authors indicated that natural antioxidant extracts were more effecient than nitrite/ nitrate and BHT. Since seabass is not considering in the high histamine produced fish species, histamine formation was not investigated in the present study.

The effects of nettle (Urticia dioica), spiny sowthistle (Sonchus asper) and dandelion (Taraxacum officinale) extract on the lipid oxidation have been investigated previously but only a few studies available about seafood. As a consequence of the present study, it is detected that those herbs have positive effects on the total quality of fish but it should be studied more detailed on compound basis.

Total volatile basic nitrogen (TVB-N) is significant feature for the evaluation of quality in fishery products and appear as the most common chemical indicator of marine fish spoilage. It was indeed established that a post-mortem decrease of trimethylamine oxide by bacterial enzymes might cause a dramatic increment in TMA-N. This process is accompanied by a significant production of ammonia and other basic nitrogenous compounds such as methylamine and dimethylamine which are collectively known as TVB-N (Dhaouadi, Monser, Sadok, \& Adhoum, 2007). TVB-N results of this study are shown in Table 2.

Table 2. TVB-N results of the samples $(\mathrm{mg} / 100 \mathrm{~g})$

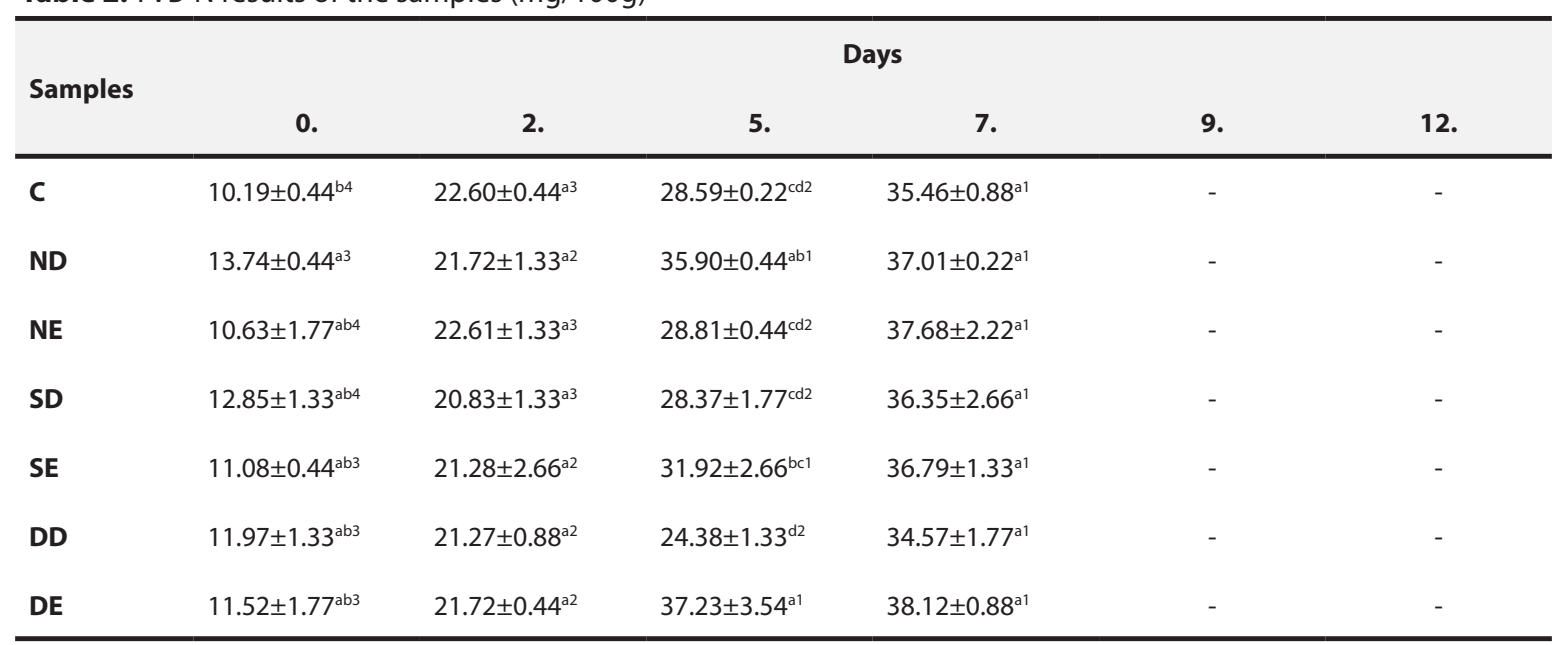

C: Control; ND: Nettle Distillate; NE: Nettle Extract; SD: Sowthistle Distillate; SE: Sowthistle Extract; DD: Dandelion Distillate; DE: Dandelion Extract

* Means in the same column with the same latter and means in the same line with the same number do not differ significantly at the level of $\mathrm{P}<0.05$ significance.

The highest TVB-N concentration was found in DE with $38.12 \mathrm{mg} / \mathrm{kg}$ and lowest in DD as $34.57 \mathrm{mg} / \mathrm{kg}$ which was the only sample below the limit at seventh day of storage. Statistically ND and DE were significantly different and have the values which passed the limit first among all included control group. At the end of day 12, TVB-N value of DD was under $35 \mathrm{mg} / 100$ $\mathrm{g}$ which is in consumable range. All other samples were exceeded the recommended limit although no significant differences were obtained. There is not any study on relations of nettle and spiny sowthistle with sea bass quality. This study is the first study which examine interactions of these herbs with sea bass. Therefore, no chance to compare to any study which was carried out with same materials. Some researchers used same herbs and different fish species and showed positive effects of them on shelf-life (Ahmadi et al., 2014; Arashisar et al., 2008). Studies on promoting effects of nettle on culturing fish were also carried out by several researchers (Bilen et al., 2016; Saeidi et al., 2017)

\section{Changes in the microbial counts}

The changes of TAMBC and PBC were shown in Table 3 and Table 4. 
Table 3. Total aerobic mezophilic bacteria counts (TAMBC log CFU/g) evaluations of groups

\begin{tabular}{|c|c|c|c|c|c|c|}
\hline \multirow{2}{*}{ Samples } & \multicolumn{6}{|c|}{ Days } \\
\hline & 0. & 2. & 5. & 7. & 9. & 12. \\
\hline C & $4.60 \pm 0.01^{\mathrm{a} 3}$ & $4.62 \pm 0.04^{\mathrm{a} 3}$ & $5.43 \pm 0.11^{\mathrm{ab} 2}$ & $7.19 \pm 0.04^{b 1}$ & - & - \\
\hline ND & $3.50 \pm 0.18^{\mathrm{c} 3}$ & $3.50 \pm 0.03^{c 3}$ & $5.53 \pm 0.11^{\mathrm{a} 2}$ & $7.47 \pm 0.11^{\mathrm{ab} 1}$ & - & - \\
\hline NE & $3.60 \pm 0.11^{\mathrm{c3}}$ & $3.50 \pm 0.04^{\mathrm{c} 3}$ & $5.35 \pm 0.16^{\mathrm{bc} 2}$ & $5.12 \pm 0.08^{c 2}$ & $7.15 \pm 0.10^{b 1}$ & - \\
\hline SD & $3.80 \pm 0.04^{\mathrm{bc} 3}$ & $4.32 \pm 0.08^{\mathrm{ab} 3}$ & $5.23 \pm 0.13^{\mathrm{bc} 2}$ & $7.60 \pm 0.45^{\mathrm{ab} 1}$ & - & - \\
\hline SE & $3.53 \pm 0.21^{c 5}$ & $4.40 \pm 0.13^{\mathrm{ab} 4}$ & $4.80 \pm 0.04^{\mathrm{d} 3}$ & $5.16 \pm 0.15^{c 2}$ & $7.05 \pm 0.03^{b 1}$ & - \\
\hline DD & $3.80 \pm 0.09^{\mathrm{bc} 4}$ & $4.25 \pm 0.18^{\mathrm{b} 3}$ & $5.11 \pm 0.07^{c 2}$ & $7.76 \pm 0.07^{\mathrm{a} 1}$ & - & - \\
\hline DE & $4.16 \pm 0.14^{b 4}$ & $4.33 \pm 0.25^{\mathrm{ab} 34}$ & $4.63 \pm 0.02^{\mathrm{d} 3}$ & $5.52 \pm 0.20^{c 2}$ & $7.39 \pm 0.02^{\mathrm{a} 1}$ & - \\
\hline
\end{tabular}

* Means in the same column with the same latter and means in the same line with the same number do not differ significantly at the level of $\mathrm{P}<0.05$ significance.

C: Control; ND: Nettle Distillate; NE: Nettle Extract; SD: Sowthistle Distillate; SE: Sowthistle Extract; DD: Dandelion Distillate; DE: Dandelion Extract

Table 4. Psychotropic bacteria counts (PBC log CFU/g) evaluations of groups

\begin{tabular}{|c|c|c|c|c|c|c|}
\hline \multirow{2}{*}{ Samples } & \multicolumn{6}{|c|}{ Days } \\
\hline & 0. & 2. & 5. & 7. & 9. & 12. \\
\hline C & $4.65 \pm 0.02^{\mathrm{a} 3}$ & $4.65 \pm 0.03^{\mathrm{a} 3}$ & $5.49 \pm 0.03^{\mathrm{a} 2}$ & $6.23 \pm 0.12^{\mathrm{ab} 1}$ & - & - \\
\hline ND & $3.57 \pm 0.08^{\mathrm{b} 4}$ & $3.76 \pm 0.04^{\mathrm{b} 3}$ & $5.21 \pm 0.09^{\mathrm{bd} 2}$ & $6.17 \pm 0.06^{\mathrm{a} 1}$ & - & - \\
\hline NE & $3.40 \pm 0.10^{\mathrm{b} 4}$ & $3.47 \pm 0.02^{c 4}$ & $5.25 \pm 0.00^{\mathrm{b} 3}$ & $5.73 \pm 0.03^{c 2}$ & $7.19 \pm 0.04^{\mathrm{a} 1}$ & - \\
\hline SD & $3.38 \pm 0.35^{\text {b3 }}$ & $3.23 \pm 0.09^{\mathrm{d} 3}$ & $4.95 \pm 0.01^{c^{2}}$ & $6.11 \pm 0.07^{\mathrm{a} 1}$ & - & - \\
\hline SE & $3.62 \pm 0.03^{b 4}$ & $4.18 \pm 0.16^{\mathrm{e} 3}$ & $5.11 \pm 0.07^{\mathrm{d} 2}$ & $5.16 \pm 0.15^{\mathrm{d} 2}$ & $6.88 \pm 0.02^{b 1}$ & - \\
\hline DD & $3.74 \pm 0.04^{\mathrm{bc}}$ & $4.17 \pm 0.06^{\mathrm{e} 3}$ & $4.91 \pm 0.00^{c 2}$ & $6.52 \pm 0.05^{\mathrm{e} 1}$ & - & - \\
\hline DE & $4.05 \pm 0.02^{c 5}$ & $4.27 \pm 0.01^{e 4}$ & $5.29 \pm 0.03^{\text {b3 }}$ & $6.44 \pm 0.08^{\text {be } 2}$ & $6.98 \pm 0.00^{\mathrm{c} 1}$ & - \\
\hline
\end{tabular}

* Means in the same column with the same latter and means in the same line with the same number do not differ significantly at the level of $\mathrm{P}<0.05$ significance.

C: Control; ND: Nettle Distillate; NE: Nettle Extract; SD: Sowthistle Distillate; SE: Sowthistle Extract; DD: Dandelion Distillate; DE: Dandelion Extract

The initial TAMBC and PBC values of control group were determined as 4.60 and $4.65 \mathrm{log} \mathrm{cfu} / \mathrm{g}$, respectively. Control group (C) and the samples treated with distillates (ND, SD, DD) reached the maximum levels at $7^{\text {th }}$ storage day according to ICMSF (1992) (limit values: $6-7 \mathrm{log} \mathrm{cfu} / \mathrm{g}$ ). Extract treated samples were reached those limits at $9^{\text {th }}$ day of storage. DE was significantly $(P<0.05)$ different at day $9^{\text {th }}$. Microbial growth was retarded by extracts in the present study (Table 3).

Astafieva et al., (2012) have reported the effects of antimicrobial peptides extracted from dandelion (Taraxacum officinale) flowers which shows correlation with this study. Gatto et al., (2011) have reported that Sonchus asper showed significant antifungal activity on fruits but T.officinale extract showed low effectiveness against all fungi despite its intermediate total phenolic concentration and its high content in chicoric acid. Aksu and Kaya, (2004) have reported that nettle (Urtica dioica) showed blocking abilities to Enterobacteriaceae and yeast/mould developing in dry fermented sausage. Alp and Aksu, (2010) demonstrated the treatment of ground beef with water extract of Urtica dioica had a small but important effect on inhibiting psychrotrophic bacteria and different microorganisms including Pseudomanas bacteria with very significant effect. 


\section{Changes in sensory values}

Results of the sensory analysis were given at Table 5 and Table 6.

Table 5. Odour and flavour evaluation of groups from sensory analysis

\begin{tabular}{|c|c|c|c|c|c|c|c|c|}
\hline & & \multicolumn{4}{|c|}{ Odour } & \multicolumn{3}{|c|}{ Flavour } \\
\hline \multicolumn{2}{|c|}{ Groups } & & & & Days & & & \\
\hline & & 0. & 2. & 5. & 7. & 0. & 2. & 5. \\
\hline \multirow{7}{*}{ 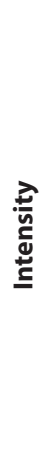 } & C & $5.60 \pm 2.61^{\mathrm{a} 1}$ & $5.80 \pm 2.68^{\mathrm{a} 1}$ & $5.20 \pm 2.05^{\mathrm{a} 1}$ & $4.60 \pm 0.89^{c 1}$ & $7.40 \pm 1.52^{\mathrm{a} 1}$ & $6.60 \pm 2.61^{\mathrm{a} 1}$ & $5.20 \pm 2.17^{\mathrm{a} 1}$ \\
\hline & ND & $6.80 \pm 2.39^{\mathrm{a} 1}$ & $6.20 \pm 2.17^{\mathrm{a} 1}$ & $5.20 \pm 1.64^{\mathrm{a} 1}$ & $4.80 \pm 0.84^{\mathrm{bc} 1}$ & $7.20 \pm 1.64^{\mathrm{a} 1}$ & $6.20 \pm 2.77^{\mathrm{a} 1}$ & $5.20 \pm 0.84^{\mathrm{a} 1}$ \\
\hline & NE & $4.00 \pm 1.73^{\mathrm{a} 12}$ & $3.20 \pm 1.79^{\mathrm{a} 2}$ & $5.60 \pm 1.67^{\mathrm{a} 12}$ & $6.00 \pm 0.71^{\mathrm{ab} 1}$ & $6.80 \pm 1.79^{\mathrm{a} 1}$ & $6.20 \pm 2.39^{\mathrm{a} 1}$ & $5.20 \pm 1.30^{\mathrm{a} 1}$ \\
\hline & SD & $3.40 \pm 2.30^{\mathrm{a} 2}$ & $3.60 \pm 2.70^{\mathrm{a} 12}$ & $6.80 \pm 1.30^{\mathrm{a} 12}$ & $7.00 \pm 0.71^{\mathrm{a} 1}$ & $6.60 \pm 2.51^{\mathrm{a} 1}$ & $6.40 \pm 2.41^{\mathrm{a} 1}$ & $5.60 \pm 1.82^{\mathrm{a} 1}$ \\
\hline & SE & $4.60 \pm 2.41^{\mathrm{a} 1}$ & $3.80 \pm 2.28^{\mathrm{a} 1}$ & $6.80 \pm 1.30^{\mathrm{a} 1}$ & $7.00 \pm 1.22^{\mathrm{a} 1}$ & $6.60 \pm 1.34^{\mathrm{a} 1}$ & $6.20 \pm 1.79^{\mathrm{a} 1}$ & $5.20 \pm 1.79^{\mathrm{a} 1}$ \\
\hline & DD & $3.20 \pm 2.77^{\mathrm{a} 1}$ & $3.40 \pm 2.19^{\mathrm{a} 1}$ & $5.80 \pm 2.39^{\mathrm{a} 1}$ & $6.00 \pm 0.71^{\mathrm{ab} 1}$ & $7.00 \pm 1.58^{\mathrm{a} 1}$ & $6.60 \pm 1.34^{\mathrm{a} 1}$ & $5.40 \pm 1.67^{\mathrm{a} 1}$ \\
\hline & DE & $6.00 \pm 1.87^{\mathrm{a} 1}$ & $5.40 \pm 1.67^{\mathrm{a} 1}$ & $6.00 \pm 1.58^{\mathrm{a} 1}$ & $6.60 \pm 1.14^{\mathrm{ab} 1}$ & $7.20 \pm 1.64^{\mathrm{a} 1}$ & $6.60 \pm 2.30^{\mathrm{a} 1}$ & $5.00 \pm 1.22^{\mathrm{a} 1}$ \\
\hline \multirow{7}{*}{ 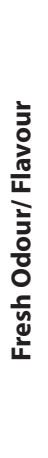 } & C & $7.40 \pm 2.61^{\mathrm{a} 1}$ & $7.00 \pm 3.08^{\mathrm{a} 1}$ & $6.20 \pm 2.49^{\mathrm{a} 1}$ & $4.00 \pm 1.22^{\mathrm{a} 1}$ & $7.40 \pm 1.52^{\mathrm{a} 1}$ & $6.80 \pm 2.28^{\mathrm{a} 1}$ & $5.60 \pm 2.88^{\mathrm{a} 1}$ \\
\hline & ND & $7.20 \pm 2.39^{\mathrm{a} 1}$ & $6.60 \pm 3.21^{\mathrm{a} 1}$ & $6.20 \pm 1.92^{\mathrm{a} 1}$ & $4.80 \pm 0.84^{\mathrm{a} 1}$ & $6.60 \pm 2.51^{\mathrm{a} 1}$ & $6.00 \pm 2.45^{\mathrm{a} 1}$ & $5.40 \pm 2.30^{\mathrm{a} 1}$ \\
\hline & NE & $6.60 \pm 2.51^{\mathrm{a} 1}$ & $5.80 \pm 2.39^{\mathrm{a} 1}$ & $6.20 \pm 1.92^{\mathrm{a} 1}$ & $5.00 \pm 0.71^{\mathrm{a} 1}$ & $7.00 \pm 1.87^{\mathrm{a} 1}$ & $6.40 \pm 2.70^{\mathrm{a} 1}$ & $6.60 \pm 2.30^{\mathrm{a} 1}$ \\
\hline & SD & $8.00 \pm 1.00^{\mathrm{a} 1}$ & $7.60 \pm 2.61^{\mathrm{a} 1}$ & $6.40 \pm 2.07^{\mathrm{a} 1}$ & $5.20 \pm 1.30^{\mathrm{a} 1}$ & $7.40 \pm 2.07^{\mathrm{a} 1}$ & $6.80 \pm 2.68^{\mathrm{a} 1}$ & $6.60 \pm 2.07^{\mathrm{a} 1}$ \\
\hline & SE & $8.00 \pm 0.71^{\mathrm{a} 1}$ & $7.60 \pm 1.14^{\mathrm{a} 12}$ & $5.00 \pm 2.55^{\mathrm{a} 23}$ & $4.80 \pm 0.84^{\mathrm{a} 3}$ & $7.80 \pm 1.30^{\mathrm{a} 1}$ & $7.20 \pm 1.92^{\mathrm{a} 1}$ & $5.80 \pm 2.59^{\mathrm{a} 1}$ \\
\hline & DD & $7.60 \pm 1.14^{\mathrm{a} 1}$ & $7.20 \pm 1.48^{\mathrm{a} 1}$ & $6.40 \pm 1.52^{\mathrm{a} 12}$ & $4.60 \pm 1.52^{\mathrm{a} 2}$ & $7.00 \pm 1.87^{\mathrm{a} 1}$ & $6.60 \pm 2.41^{\mathrm{a} 1}$ & $7.20 \pm 1.79^{\mathrm{a} 1}$ \\
\hline & DE & $7.00 \pm 2.35^{\mathrm{a} 1}$ & $6.80 \pm 2.77^{\mathrm{a} 1}$ & $5.80 \pm 1.64^{\mathrm{a} 1}$ & $4.80 \pm 1.48^{\mathrm{a} 1}$ & $7.80 \pm 1.64^{\mathrm{a} 1}$ & $7.20 \pm 3.03^{a 1}$ & $5.60 \pm 2.07^{\mathrm{a} 1}$ \\
\hline \multirow{7}{*}{ 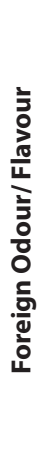 } & C & $1.20 \pm 0.45^{\mathrm{b} 1}$ & $1.20 \pm 0.45^{\mathrm{b} 1}$ & $1.40 \pm 0.55^{\mathrm{a} 1}$ & $1.20 \pm 0.45^{\mathrm{b} 1}$ & $1.40 \pm 0.55^{\mathrm{a} 1}$ & $1.40 \pm 0.55^{\mathrm{a} 1}$ & $2.20 \pm 1.64^{\mathrm{a} 1}$ \\
\hline & ND & $2.60 \pm 0.55^{\mathrm{a} 1}$ & $3.00 \pm 1.58^{\mathrm{a} 1}$ & $1.80 \pm 0.84^{\mathrm{a} 1}$ & $2.60 \pm 0.89^{\mathrm{ab} 1}$ & $2.00 \pm 1.73^{\mathrm{a} 1}$ & $2.20 \pm 2.17^{\mathrm{a} 1}$ & $3.00 \pm 1.58^{\mathrm{a} 1}$ \\
\hline & NE & $1.40 \pm 0.55^{\mathrm{b} 1}$ & $1.40 \pm 0.55^{\mathrm{b} 1}$ & $1.60 \pm 0.55^{\mathrm{a} 1}$ & $1.60 \pm 0.89^{\mathrm{b} 1}$ & $1.40 \pm 0.55^{\mathrm{a} 1}$ & $1.80 \pm 1.30^{\mathrm{a} 1}$ & $2.80 \pm 1.48^{\mathrm{a} 1}$ \\
\hline & SD & $1.20 \pm 0.45^{\mathrm{b} 1}$ & $1.20 \pm 0.45^{\mathrm{b} 1}$ & $2.20 \pm 1.30^{\mathrm{a} 1}$ & $2.40 \pm 0.55^{\mathrm{ab} 1}$ & $1.40 \pm 0.55^{\mathrm{a} 1}$ & $1.60 \pm 0.89^{\mathrm{a} 1}$ & $3.00 \pm 1.58^{\mathrm{a} 1}$ \\
\hline & SE & $1.40 \pm 0.55^{\mathrm{b} 1}$ & $1.60 \pm 0.55^{\mathrm{ab} 1}$ & $4.20 \pm 3.11^{\mathrm{a} 1}$ & $4.40 \pm 1.95^{\mathrm{a} 1}$ & $1.20 \pm 0.45^{\mathrm{a} 1}$ & $1.40 \pm 0.55^{\mathrm{a} 1}$ & $3.00 \pm 1.87^{\mathrm{a} 1}$ \\
\hline & DD & $1.00 \pm 0.00^{\mathrm{b} 1}$ & $1.20 \pm 0.45^{\mathrm{b} 1}$ & $2.80 \pm 2.95^{\mathrm{a} 1}$ & $3.00 \pm 0.71^{\mathrm{ab} 1}$ & $1.20 \pm 0.45^{\mathrm{a} 2}$ & $1.20 \pm 0.45^{\mathrm{a} 2}$ & $2.80 \pm 1.48^{\mathrm{a} 1}$ \\
\hline & DE & $1.40 \pm 0.55^{\mathrm{b} 1}$ & $1.20 \pm 0.45^{\mathrm{b} 1}$ & $3.00 \pm 2.92^{\mathrm{a} 1}$ & $3.20 \pm 0.84^{\mathrm{ab} 1}$ & $1.20 \pm 0.45^{\mathrm{a} 2}$ & $1.20 \pm 0.45^{\mathrm{a} 2}$ & $2.40 \pm 0.89^{\mathrm{a} 1}$ \\
\hline
\end{tabular}

C: Control; ND: Nettle Distillate; NE: Nettle Extract; SD: Sowthistle Distillate; SE: Sowthistle Extract; DD: Dandelion Distillate; DE: Dandelion Extract

* Means in the same column with the same latter and means in the same line with the same number do not differ significantly at the level of $\mathrm{P}<0.05$ significance. Statistical evaluations for Table 5 were carried out for odour and flavour individually. 
Table 6. Texture evaluation of groups from sensory analysis

\begin{tabular}{|c|c|c|c|c|c|c|c|}
\hline \multirow{2}{*}{\multicolumn{2}{|c|}{ Groups }} & \multicolumn{6}{|c|}{ Days } \\
\hline & & 0. & 2. & 5. & 7. & 9. & 12. \\
\hline \multirow{7}{*}{ 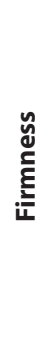 } & C & $7.60 \pm 1.67^{\mathrm{a} 1}$ & $7.20 \pm 2.17^{\mathrm{a} 1}$ & $5.40 \pm 1.95^{\mathrm{a} 1}$ & $4.80 \pm 1.79^{\mathrm{a} 1}$ & - & - \\
\hline & ND & $7.00 \pm 2.35^{\mathrm{a} 1}$ & $6.60 \pm 2.30^{\mathrm{a} 1}$ & $6.00 \pm 1.58^{\mathrm{a} 1}$ & $5.40 \pm 1.52^{\mathrm{a} 1}$ & - & - \\
\hline & NE & $6.80 \pm 2.05^{\mathrm{a} 1}$ & $6.20 \pm 2.59^{\mathrm{a} 1}$ & $6.00 \pm 1.58^{\mathrm{a} 1}$ & $5.80 \pm 0.84^{a 1}$ & - & - \\
\hline & SD & $8.20 \pm 0.84^{\mathrm{a} 1}$ & $7.60 \pm 1.67^{\mathrm{a} 12}$ & $6.00 \pm 1.22^{\mathrm{a} 12}$ & $5.40 \pm 1.67^{\mathrm{a} 2}$ & - & - \\
\hline & SE & $7.20 \pm 1.30^{\mathrm{a} 1}$ & $6.80 \pm 2.05^{\mathrm{a} 1}$ & $6.60 \pm 0.89^{\mathrm{a} 1}$ & $5.60 \pm 1.82^{\mathrm{a} 1}$ & - & - \\
\hline & DD & $7.20 \pm 1.79^{\mathrm{a} 1}$ & $6.60 \pm 2.30^{a 1}$ & $5.80 \pm 1.79^{\mathrm{a} 1}$ & $5.20 \pm 1.30^{\mathrm{a} 1}$ & - & - \\
\hline & $\mathrm{DE}$ & $7.20 \pm 2.17^{\mathrm{a} 1}$ & $6.80 \pm 2.17^{\mathrm{a} 1}$ & $5.80 \pm 2.28^{\mathrm{a} 1}$ & $5.20 \pm 1.92^{\mathrm{a} 1}$ & - & - \\
\hline \multirow{7}{*}{ 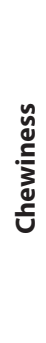 } & C & $7.20 \pm 1.48^{\mathrm{a} 1}$ & $6.00 \pm 2.24^{\mathrm{a} 1}$ & $5.40 \pm 2.30^{\mathrm{a} 1}$ & $4.80 \pm 1.79^{\mathrm{a} 1}$ & - & - \\
\hline & ND & $6.20 \pm 1.92^{\mathrm{a} 1}$ & $5.20 \pm 2.86^{\mathrm{a} 1}$ & $5.80 \pm 1.92^{\mathrm{a} 1}$ & $4.80 \pm 1.10^{\mathrm{a} 1}$ & - & - \\
\hline & NE & $6.80 \pm 1.64^{\mathrm{a} 1}$ & $5.20 \pm 2.59^{\mathrm{a} 1}$ & $6.00 \pm 2.00^{\mathrm{a} 1}$ & $5.20 \pm 1.79^{\mathrm{a} 1}$ & - & - \\
\hline & SD & $5.60 \pm 2.88^{\mathrm{a} 1}$ & $5.20 \pm 2.77^{\mathrm{a} 1}$ & $5.80 \pm 1.48^{\mathrm{a} 1}$ & $5.00 \pm 0.71^{\mathrm{a} 1}$ & - & - \\
\hline & SE & $6.40 \pm 1.82^{\mathrm{a} 1}$ & $5.80 \pm 2.28^{\mathrm{a} 1}$ & $6.60 \pm 1.14^{\mathrm{a} 1}$ & $5.40 \pm 1.34^{\mathrm{a} 1}$ & - & - \\
\hline & DD & $6.20 \pm 1.92^{\mathrm{a} 1}$ & $5.60 \pm 2.41^{\mathrm{a} 1}$ & $6.00 \pm 2.12^{\mathrm{a} 1}$ & $4.60 \pm 1.82^{\mathrm{a} 1}$ & - & - \\
\hline & DE & $5.60 \pm 2.61^{\mathrm{a} 1}$ & $5.60 \pm 2.51^{\mathrm{a} 1}$ & $6.20 \pm 2.05^{\mathrm{a} 1}$ & $5.20 \pm 0.84^{\mathrm{a} 1}$ & - & - \\
\hline \multirow{7}{*}{ 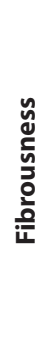 } & C & $5.80 \pm 1.64^{\mathrm{a} 1}$ & $4.00 \pm 2.55^{\mathrm{a} 1}$ & $3.80 \pm 2.05^{\mathrm{a} 1}$ & $3.60 \pm 1.52^{\mathrm{a} 1}$ & - & - \\
\hline & ND & $5.20 \pm 3.35^{\mathrm{a} 1}$ & $4.80 \pm 3.03^{\mathrm{a} 1}$ & $4.60 \pm 2.41^{\mathrm{a} 1}$ & $4.20 \pm 1.64^{\mathrm{a} 1}$ & - & - \\
\hline & NE & $5.60 \pm 3.58^{\mathrm{a} 1}$ & $5.00 \pm 3.39^{\mathrm{a} 1}$ & $4.80 \pm 2.17^{\mathrm{a} 1}$ & $4.20 \pm 1.79^{\mathrm{a} 1}$ & - & - \\
\hline & SD & $6.20 \pm 3.11^{\mathrm{a} 1}$ & $5.80 \pm 3.42^{\mathrm{a} 1}$ & $4.40 \pm 1.82^{\mathrm{a} 1}$ & $4.00 \pm 1.41^{\mathrm{a} 1}$ & - & - \\
\hline & SE & $4.60 \pm 2.41^{\mathrm{a} 1}$ & $4.40 \pm 3.21^{\mathrm{a} 1}$ & $4.80 \pm 2.17^{\mathrm{a} 1}$ & $4.20 \pm 2.05^{a 1}$ & - & - \\
\hline & DD & $4.80 \pm 2.17^{\mathrm{a} 1}$ & $4.40 \pm 2.88^{\mathrm{a} 1}$ & $4.40 \pm 2.61^{\mathrm{a} 1}$ & $4.00 \pm 2.00^{\mathrm{a} 1}$ & - & - \\
\hline & $\mathrm{DE}$ & $4.60 \pm 3.21^{\mathrm{a} 1}$ & $4.20 \pm 3.42^{\mathrm{a} 1}$ & $4.40 \pm 2.30^{\mathrm{a} 1}$ & $4.20 \pm 1.79^{\mathrm{a} 1}$ & - & - \\
\hline \multirow{7}{*}{ 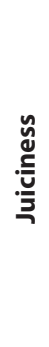 } & C & $5.80 \pm 2.59^{\mathrm{a} 1}$ & $5.00 \pm 3.39^{\mathrm{a} 1}$ & $5.60 \pm 2.30^{\mathrm{a} 1}$ & $4.80 \pm 1.92^{\mathrm{a} 1}$ & - & - \\
\hline & ND & $6.80 \pm 1.79^{\mathrm{a} 1}$ & $6.00 \pm 2.74^{\mathrm{a} 1}$ & $5.60 \pm 2.30^{\mathrm{a} 1}$ & $4.80 \pm 1.30^{\mathrm{a} 1}$ & - & - \\
\hline & NE & $6.60 \pm 2.30^{\mathrm{a} 1}$ & $5.60 \pm 3.13^{\mathrm{a} 1}$ & $6.00 \pm 1.58^{\mathrm{a} 1}$ & $5.00 \pm 1.00^{\mathrm{a} 1}$ & - & - \\
\hline & SD & $6.20 \pm 2.77^{\mathrm{a} 1}$ & $4.60 \pm 3.58^{\mathrm{a} 1}$ & $5.60 \pm 1.67^{\mathrm{a} 1}$ & $4.80 \pm 0.84^{\mathrm{a} 1}$ & - & - \\
\hline & SE & $6.20 \pm 2.59^{\mathrm{a} 1}$ & $5.20 \pm 2.59^{\mathrm{a} 1}$ & $5.60 \pm 2.30^{\mathrm{a} 1}$ & $4.60 \pm 1.95^{\mathrm{a} 1}$ & - & - \\
\hline & DD & $6.20 \pm 2.17^{\mathrm{a} 1}$ & $5.60 \pm 2.51^{\mathrm{a} 1}$ & $6.40 \pm 2.07^{\mathrm{a} 1}$ & $5.80 \pm 1.30^{\mathrm{a} 1}$ & - & - \\
\hline & DE & $6.40 \pm 2.07^{\mathrm{a} 1}$ & $5.40 \pm 2.88^{\mathrm{a} 1}$ & $6.20 \pm 2.05^{\mathrm{a} 1}$ & $5.20 \pm 1.79^{a 1}$ & - & - \\
\hline \multirow{7}{*}{ 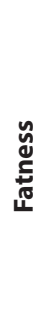 } & C & $4.20 \pm 1.10^{\mathrm{a} 1}$ & $4.20 \pm 2.05^{\mathrm{a} 1}$ & $3.60 \pm 1.14^{\mathrm{a} 1}$ & $3.00 \pm 1.41^{\mathrm{a} 1}$ & - & - \\
\hline & ND & $4.00 \pm 1.41^{\mathrm{a} 1}$ & $3.80 \pm 1.64^{\mathrm{a} 1}$ & $3.60 \pm 1.14^{\mathrm{a} 1}$ & $3.20 \pm 0.84^{\mathrm{a} 1}$ & - & - \\
\hline & NE & $4.80 \pm 0.45^{\mathrm{a} 1}$ & $3.80 \pm 1.30^{\mathrm{a} 1}$ & $4.00 \pm 0.71^{\mathrm{a} 1}$ & $3.40 \pm 0.55^{\mathrm{a} 1}$ & - & - \\
\hline & SD & $4.20 \pm 0.84^{\mathrm{a} 1}$ & $3.40 \pm 1.52^{\mathrm{a} 1}$ & $3.80 \pm 1.10^{\mathrm{a} 1}$ & $3.40 \pm 1.14^{\mathrm{a} 1}$ & - & - \\
\hline & SE & $4.20 \pm 1.10^{\mathrm{a} 1}$ & $3.60 \pm 1.34^{\mathrm{a} 1}$ & $3.40 \pm 1.34^{\mathrm{a} 1}$ & $3.80 \pm 1.30^{\mathrm{a} 1}$ & - & - \\
\hline & DD & $4.00 \pm 1.00^{\mathrm{a} 1}$ & $4.00 \pm 1.00^{\mathrm{a} 1}$ & $4.20 \pm 0.84^{\mathrm{a} 1}$ & $4.20 \pm 0.45^{\mathrm{a} 1}$ & - & - \\
\hline & DE & $4.00 \pm 1.00^{\mathrm{a} 1}$ & $3.80 \pm 1.30^{\mathrm{a} 1}$ & $3.60 \pm 1.14^{\mathrm{a} 1}$ & $3.80 \pm 0.84^{\mathrm{a} 1}$ & - & - \\
\hline
\end{tabular}

* Means in the same column with the same latter and means in the same line with the same number do not differ -significantly at the level of $\mathrm{P}<0.05$ significance.

C: Control; ND: Nettle Distillate; NE: Nettle Extract; SD: Sowthistle Distillate; SE: Sowthistle Extract; DD: Dandelion Distillate; DE: Dandelion Extract 
Statistically, from the points of taste and flavour, all samples were accepted by panellists but extract treated samples have lost the score among others after day 5 . For odour, there are no significant differences between groups until day 7. C and ND are low, SD and SE high in intensity, SE was high in foreign odour, no significant differences between all samples for fresh odour at $7^{\text {th }}$ day. There are no significant differences between all groups in texture and flavour evaluation. Highest and lowests scores of mean values of odour test were given for intensity by: $D E=6.0 / N E=4.7$, for fresh odour by: $\mathrm{SD}=6.8 / \mathrm{NE}=5.9$ and for foreign odour by: $S E=2.9 / C=1.25$. Scores of flavour evaluation as follows; For Intensity: $C=6.33 / \mathrm{SE}=6.0$, for fresh odour: $\mathrm{SD}=\mathrm{SE}=\mathrm{DD}=6.93 / \mathrm{ND}=6$ and for foreign odour: $\mathrm{ND}=2.4 /$ $C=1.25$. Highest and lowest scores of mean values of texture evaluation were given for intensity by: $S D=6.8$ / $\mathrm{NE}=\mathrm{DD}=6.2$, for chewiness by: $\mathrm{SE}=6.05 / \mathrm{SD}=5.4$, for fibrousness by: $S D=5.1 / C=D E=4.3$, for juiciness by:

\section{REFERENCES}

Ahmadi, M., Razavilar, V., Motallebi, A. ., Esmailzadeh Kenari, R. \& Khanipour, A. (2014). Effects of Hydroalcoholic and Water Extracts of Nettle Leaf (Urtica dioica L.) on Chemical Properties of Superchilled Minced Meat of Common Kilka (Clupeonella cultriventris caspia). Journal of Food Quality and Hazards Control, 1(3), 85-88. Retrieved from http://jfqhc.ssu.ac.ir/browse.php?a_ id $=72 \&$ sid $=1 \&$ slc_lang $=f a$

Aksu, M. \& Kaya, M. (2004). Effect of usage Urtica dioica L. on microbiological properties of sucuk, a Turkish dry-fermented sausage. Food Control, 15(8), 591-595.

DOI: 10.1016/J.FOODCONT.2003.09.006

Alirezalu, K., Hesari, J., Eskandari, M. H., Valizadeh, H. \& Sirousazar M. (2017). Effect of Green Tea, Stinging Nettle and Olive Leaves Extracts on the Quality and Shelf Life Stability of Frankfurter Type Sausage. Journal of Food Processing and Preservation, 41(5), e13100. DOI: 10.1111/jfpp.13100

Alp, E. \& Aksu, M. İ. (2010). Effects of water extract of Urtica dioica $\mathrm{L}$. and modified atmosphere packaging on the shelf life of ground beef. Meat Science, 86(2), 468-473.

DOI: 10.1016/J.MEATSCI.2010.05.036

Alpınar, K., Özyürek, M., Kolak, U., Güçlü, K., Aras, Ç., Altun, M., ... Apak, R. (2009). Antioxidant Capacities of Some Food Plants Wildly Grown in Ayvalik of Turkey. Food Science and Technology Research, 15(1), 59-64. DOI: 10.3136/fstr.15.59

Arashisar, S., Hisar, O., Kaban, G., Kaya, M., Gulcin, I. \& Yanik, T. (2008). The Effects of Nettle (Urtica diocia L.) on Chemical Properties of Rainbow Trout (Oncorynchus mykiss) Fillets. American Journal of Food Technology, 3(5), 335-340. DOI: 10.3923/ajft.2008.335.340

Ariyapitipun, T., Mustapha, A. \& Clarke, A. D. (1999). Microbial Shelf Life Determination of Vacuum-Packaged Fresh Beef Treated with Polylactic Acid, Lactic Acid, and Nisin Solutions. Journal of Food Protection, 62(8), 913-920. DOI: 10.4315/0362-028X-62.8.913

Astafieva, A. A., Rogozhin, E. A., Odintsova, T. I., Khadeeva, N. V., Grishin, E. V. \& Egorov, T. A. (2012). Discovery of novel antimicrobial peptides with unusual cysteine motifs in dandelion Taraxacum officinale Wigg. flowers. Peptides, 36(2), 266-271.
$\mathrm{DD}=6.0 / \mathrm{C}=\mathrm{SD}=5.3$ and for fatness by: $\mathrm{DD}=4.1 / \mathrm{ND}=3.65$.

\section{CONCLUSION}

There is no significant differences between all for TVB-N values in day 7 but, dandelion distillate treated sample was the only one which has value in acceptable limit in that day. All TBA values were very low and in consumable limit. All extract treated samples were effective as antimicrobial by retarding microbial spoilage for one analysing period. In sensorial analysis, all samples have shown correlation with control group except for intensity of ND as low, SD, SE as high. SE was determined also high for foreign odour.

The most important finding is that extracted samples showed microbial growth retarding ability and we concluded that, some herbs such as nettle, dandelion and spiny sowthistle can be used as preservative in seafood processing to protect the quality and prolong the shelf-life.

DOI: 10.1016/J.PEPTIDES.2012.05.009

Avcı, G., Kupeli, E., Eryavuz, A., Yesilada, E. \& Kucukkurt, I. (2006). Antihypercholesterolaemic and antioxidant activity assessment of some plants used as remedy in Turkish folk medicine. Journal of Ethnopharmacology, 107(3), 418-423. DOI: 10.1016/J.JEP.2006.03.032

Biel, W., Jaroszewska, A., Łysoń, E. \& Telesiński, A. (2017). THE CHEMICAL COMPOSITION AND ANTIOXIDANT PROPERTIES OF COMMON DANDELION LEAVES COMPARED TO SEA BUCKTHORN. Canadian Journal of Plant Science, CJPS-2016-0409. DOI: 10.1139/CJPS-2016-0409

Bilen, S., Ünal, S. \& Güvensoy, H. (2016). Effects of oyster mushroom (Pleurotus ostreatus) and nettle (Urtica dioica) methanolic extracts on immune responses and resistance to Aeromonas hydrophila in rainbow trout (Oncorhynchus mykiss). Aquaculture, 454, 90-94. DOI: 10.1016/J.AQUACULTURE.2015.12.010

Bnouham, M., Merhfour, F.-Z., Ziyyat, A., Mekhfi, H., Aziz, M. \& Legssyer, A. (2003). Antihyperglycemic activity of the aqueous extract of Urtica dioica. Fitoterapia, 74(7-8), 677-681. DOI: 10.1016/S0367-326X(03)00182-5

Carbonell, I, Izquierdo, L. \& Costell, E. (2002). Sensory Profiling of Cooked Gilthead Sea Bream (Sparus aurata): Sensory Evaluation Procedures and Panel Training. Food Science and Technology International, 8(3), 169-177. DOI: 10.1106/108201302026641

Cho, S.-Y., Park, J.-Y., Park, E.-M., Choi, M.-S., Lee, M.-K., Jeon, S.-M., .. Park, Y. B. (2002). Alternation of hepatic antioxidant enzyme activities and lipid profile in streptozotocin-induced diabetic rats by supplementation of dandelion water extract. Clinica Chimica Acta, 317(1-2), 109-117. DOI: 10.1016/S0009-8981(01)00762-8

Choi, U.-K., Lee, O.-H., Yim, J. H., Cho, C.-W., Rhee, Y. K., Lim, S.-I., \& Kim, Y.-C. (2010). Hypolipidemic and Antioxidant Effects of Dandelion (Taraxacum officinale) Root and Leaf on Cholesterol-Fed Rabbits. International Journal of Molecular Sciences, 11(1), 67-78. DOI: 10.3390/ijms11010067

Dhaouadi, A., Monser, L., Sadok, S. \& Adhoum, N. (2007). Validation of a flow-injection-gas diffusion method for total volatile basic nitrogen determination in seafood products. Food Chemistry, 103(3), 1049-1053. DOI: 10.1016/J.FOODCHEM.2006.07.066

El-Alim, S. S. L. A., Lugasi, A., Hovari, J. \& Dworschak, E. (1999). 
Culinary herbs inhibit lipid oxidation in raw and cooked minced meat patties during storage. Journal of the Science of Food and Agriculture, 79(2), 277-285.

DOI:10.1002/(SICI)1097-0010(199902)79:2<277::AID-JSFA181>3.0.CO;2-S

Frankel, E. N., Huang, S.-W., Prior, E. \& Aeschbach, R. (1996). Evaluation of Antioxidant Activity of Rosemary Extracts, Carnosol and Carnosic Acid in Bulk Vegetable Oils and Fish Oil and Their Emulsions. Journal of the Science of Food and Agriculture, 72(2), 201-208.

DOI:10.1002/(SICI)1097-0010(199610)72:2<201::AID-JSFA632>3.0.CO;2-O

Gatto, M. A., Ippolito, A., Linsalata, V., Cascarano, N. A., Nigro, F. Vanadia, S. \& Di Venere, D. (2011). Activity of extracts from wild edible herbs against postharvest fungal diseases of fruit and vegetables. Postharvest Biology and Technology, 61(1), 72-82. DOI: 10.1016/J.POSTHARVBIO.2011.02.005

Gülçin, İ., Küfrevioğlu, Ö. İ., Oktay, M. \& Büyükokuroğlu, M. E. (2004). Antioxidant, antimicrobial, antiulcer and analgesic activities of nettle (Urtica dioica L.). Journal of Ethnopharmacology, 90(2-3), 205-215. DOI: 10.1016/J.JEP.2003.09.028

Haghju, S., Beigzadeh, S., Almasi, H. \& Hamishehkar, H. (2016) Chitosan films incorporated with nettle (Urtica dioica L.) extractloaded nanoliposomes: I. Physicochemical characterisation and antimicrobial properties. Journal of Microencapsulation, 33(5), 438-448. DOI: 10.1080/02652048.2016.1208294

Hu, C. \& Kitts, D. D. (2005). Dandelion (Taraxacum officinale) flower extract suppresses both reactive oxygen species and nitric oxide and prevents lipid oxidation in vitro. Phytomedicine, 12(8), 588597. DOI: 10.1016/J.PHYMED.2003.12.012

ICMSF. (1992). International commission on microbiological specifications for foods. Sampling plans for fish and shellfish. In ICMSF (Ed.), Microorganisms in foods. Sampling for microbiological analysis: Principles and scientific applications, 2nd ed. Toronto, Canada: University of Toronto Press.

Ivanov, I. G. (2014). Polyphenols Content and Antioxidant Activities of Taraxacum officinale F.H. Wigg (Dandelion) Leaves. Available Online on Www.ljppr.Com International Journal of Pharmacognosy and Phytochemical Research, 6(4). Retrieved from www.ijppr.com

Karabacak, S. \& Bozkurt, H. (2008). Effects of Urtica dioica and Hibiscus sabdariffa on the quality and safety of sucuk (Turkish dry-fermented sausage). Meat Science, 78(3), 288-296. DOI: 10.1016/J.MEATSCI.2007.06.013

Khan, R. A. (2017). Antidiabetic, Antioxidant, and Hypolipidemic Potential of Sonchus asper Hill. Alternative Therapies in Health and Medicine, 23(5), 34-40. Retrieved from http://www.ncbi.nlm. nih.gov/pubmed/28236622

Khan, R. A., Khan, M. R. \& Sahreen, S. (2012). Protective effect of Sonchus asper extracts against experimentally induced lung injuries in rats: A novel study. Experimental and Toxicologic Pathology, 64(7-8), 725-731. DOI: 10.1016/J.ETP.2011.01.007

Malle, P. \& Poumeyrol, M. (1989). A New Chemical Criterion for the Quality Control of Fish: Trimethylamine/Total Volatile Basic Nitrogen (\%). Journal of Food Protection, 52(6), 419-423. DOI: 10.4315/0362-028X-52.6.419

Mavi, A., Terzi, Z., Özgen, U., Yildirim, A. \& Cosskun, M. (2004) Antioxidant Properties of Some Medicinal Plants: Prangos ferulacea (Apiaceae), Sedum sempervivoides (Crassulaceae), Malva neglecta (Malvaceae), Cruciata taurica (Rubiaceae), Rosa pimpinellifolia (Rosaceae), Galium verum subsp. verum (Rubiaceae), Urtica dioica (Urticaceae). Biological \& Pharmaceutical Bulletin, 27(5), 702-705. DOI: 10.1248/bpb.27.702
Ovadje, P., Chatterjee, S., Griffin, C., Tran, C., Hamm, C. \& Pandey, S. (2011). Selective induction of apoptosis through activation of caspase- 8 in human leukemia cells (Jurkat) by dandelion root extract. Journal of Ethnopharmacology, 133(1), 86-91. DOI: 10.1016/J.JEP.2010.09.005

Oz, F. (2014). Effects of Water Extract of Urtica dioica L. on the Quality of Meatballs. Journal of Food Processing and Preservation, 38(3), 1356-1363. DOI: 10.1111/jfpp.12097

Özen, T. \& Korkmaz, H. (2003). Modulatory effect of Urtica dioica L. (Urticaceae) leaf extract on biotransformation enzyme systems, antioxidant enzymes, lactate dehydrogenase and lipid peroxidation in mice. Phytomedicine, 10(5), 405-415. DOI: 10.1078/0944-7113-00275

Ozyurt, D., Demirata, B. \& Apak, R. (2007). Determination of total antioxidant capacity by a new spectrophotometric method based on $\mathrm{Ce}(\mathrm{IV})$ reducing capacity measurement. Talanta, 71(3), 1155-1165. DOI: 10.1016/J.TALANTA.2006.06.015

Randall, C., Meethan, K., Randall, H. \& Dobbs, F. (1999). Nettle sting of Urtica dioica for joint pain - an exploratory study of this complementary therapy. Complementary Therapies in Medicine, 7(3), 126-131. DOI: 10.1016/S0965-2299(99)80119-8

Rohde, R. (2007). W.F. Harrigan and Margaret, F. McCance (Editors), Laboratory Methods in Food and Dairy Microbiology (Revised Edition). 452 S., 24 Abb. London-New York-San Francisco 1976. Academic Press. $£$ 9.20. Zeitschrift Für Allgemeine Mikrobiologie, 18(3), 226-227. DOI: 10.1002/jobm.19780180316

Saeidi asl, M.R., Adel, M., Caipang, C.M.A. \& Dawood, M.A.O. (2017). Immunological responses and disease resistance of rainbow trout (Oncorhynchus mykiss) juveniles following dietary administration of stinging nettle (Urtica dioica). Fish \& Shellfish Immunology, 71, 230-238.

DOI: $10.1016 /$ j.fsi.2017.10.016

Shah, M. A., Bosco, S. J. D. \& Mir, S. A. (2014). Plant extracts as natural antioxidants in meat and meat products. Meat Science, 98(1), 21-33. DOI: 10.1016/J.MEATSCI.2014.03.020

Tan, X., Sun, Z., Zhou, C., Huang, Z., Tan, L., Xun, P., ... Wang, A. (2018). Effects of dietary dandelion extract on intestinal morphology, antioxidant status, immune function and physical barrier function of juvenile golden pompano Trachinotus ovatus. Fish \& Shellfish Immunology, 73, 197-206. DOI: 10.1016/J.FSI.2017.12.020

Tarladgis, B.G., Watts, B.M., Younathan, M.T. \& Dugan, L. (1960). A distillation method for the quantitative determination of malonaldehyde in rancid foods. Journal of the American Oil Chemists' Society, 37(1), 44-48. DOI: 10.1007/BF02630824

Testai, L., Chericoni, S., Calderone, V., Nencioni, G., Nieri, P., Morelli, I., \& Martinotti, E. (2002). Cardiovascular effects of Urtica dioica $\mathrm{L}$. (Urticaceae) roots extracts: in vitro and in vivo pharmacological studies. Journal of Ethnopharmacology, 81(1), 105-109. DOI: 10.1016/S0378-8741(02)00055-7

Toldy, A., Stadler, K., Sasvári, M., Jakus, J., Jung, K. J., Chung, H. Y., ... Radák, Z. (2005).The effect of exercise and nettle supplementation on oxidative stress markers in the rat brain. Brain Research Bulletin, 65(6), 487-493. DOI: 10.1016/J.BRAINRESBULL.2005.02.028

Yener, Z., Celik, I., Ilhan, F. \& Bal, R. (2009). Effects of Urtica dioica L. seed on lipid peroxidation, antioxidants and liver pathology in aflatoxin-induced tissue injury in rats. Food and Chemical Toxicology, 47(2), 418-424. DOI: 10.1016/J.FCT.2008.11.031 